\title{
Variation and significance of egg mass in a Pied Flycatcher Ficedula hypoleuca population in subalpine habitats in Swedish Lapland
}

\author{
Variation och betydelse av äggvikter hos en svartvit flugsnapparpopulation \\ Ficedula hypoleuca $i$ fjällbjörkskog $i$ svenska Lappland
}

\author{
N. ERIK I. NYHOLM
}

Newly laid eggs of Pied Flycatchers Ficedula hypoleuca
breeding in subalpine birch forest in Swedish Lapland
were weighed in the field in $1965-1976$. The main objec-
tive of the study was to get knowledge of the egg produc-
tion capacity and its relation to the environmental condi-
tions in the northern periphery of the breeding range of
the species. The eggs were on average smaller than what
is known from other Pied Flycatcher populations. Egg
mass was non-linearly related to ambient temperature,
and smallest at temperatures $<10^{\circ} \mathrm{C}$. About $70 \%$ of the
eggs were laid at those temperatures. Variation in tem-
peratures during the egg formation contributed to a sig-

nificant egg mass variation between years. Average egg mass was lowest in the biggest clutches ( 7 or 8 eggs). Egg mass did not vary significantly within clutches, was not significantly related to the female mass, and did not vary between years in the same female. Hatching and fledging success were non-significantly related to the mean egg masses, indicating that egg sizes were not decisive for the breeding output.

Erik Nyholm, Sörfors 550, 90588 Umeå. E-mail: erik. nyholm@sorfors.se

Received 27 November 2014, Accepted 25 October 2015, Editor: Å. Lindström

\section{Introduction}

This study of a population of Pied Flycatchers Ficedula hypoleuca breeding in nest boxes in subalpine birch forest habitats at Ammarnäs, northern Sweden, was carried out in 1965-1976. When the study started it was the first to explore the breeding biology of the Pied Flycatcher in subalpine habitats. The species has expanded its distribution range northwards from the European continent relatively recently, to become a frequent breeder over most of Scandinavia during the two latest centuries (cf. Lundberg \& Alatalo 1992). The subalpine birch forest represents the most peripheral northern habitats within the Scandinavian range of the Pied Flycatcher. Here, the course of breeding could be expected to be affected by environmental factors, e.g. by harsh and unpredictable climatic conditions. This raised questions about its breeding biology in these habitats, here specifically the egg production capacity. To get the most detailed measure of the egg production it was decided to study the continuous variable egg mass in addition to clutch size. This paper reports and discusses the mass variation of Pied Flycatcher eggs at Ammarnäs in relation to season, clutch size, position in the laying sequence, female mass, ambient temperature, habitat quality, and breeding success during twelve breeding seasons.

\section{Study area and methods}

The data reported here come from 1965-1976 and are a part of a still ongoing study of the breeding biology of the Pied Flycatcher Ficedula hypoleuca Pallas (Nyholm 2011). The study was performed in nest-box breeding populations in subalpine birch forest at 500 to $600 \mathrm{~m}$. a.s.l. on the south-facing slopes of the mountains Gaissats and Valle, 5-10 $\mathrm{km}$ west of Ammarnäs, Swedish Lapland, approximately $65^{\circ} 58^{\prime} \mathrm{N}, 16^{\circ} \mathrm{E}$. The study area is described more in detail by Nyholm (2011).

Eggs were weighed in the field by means of a balance based on the electromagnetic weighing principle, which was constructed especially for weighing eggs of smaller birds in the field (Nyholm \& Ginstrup 1968). The balance was calibrated daily by means of a $1 \mathrm{~g}$ standard weight, giving accuracy within $\pm 0.01 \mathrm{~g}$. 


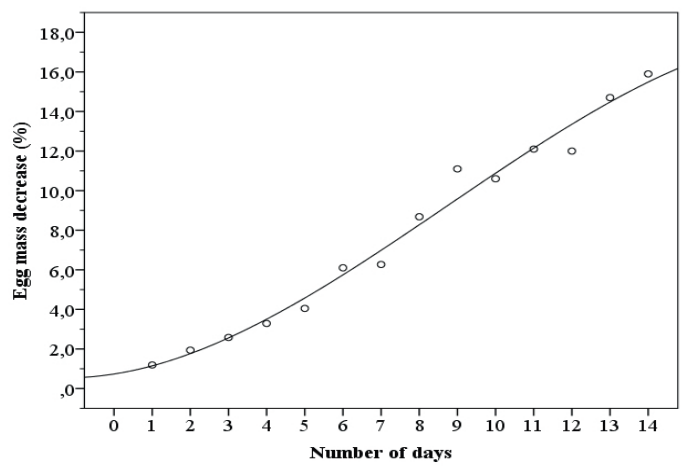

Figure 1. Cumulative mean egg mass decrease (\%) during incubation (Line according to cubic regression model: $\mathrm{r}^{2}=$ 0.98).

Kumulativ minskning (\%) av medelvikten hos ägg under ruvningsperioden.

Standard deviation and number of clutches (within parenthesis) were as follows for the 14 values in the diagram; Standardavvikelsen och antal kullar (inom parentes) var följande för de 14 värdena i diagrammet: 0.42(18), 0.77(21), 0.42(7), $0.70(11), 1.38(9), 2.23(15), 1.63(13), 2.14(10), 2.87(7)$, 2.35(8), 3.33(12), 2.72(15), 2.45(7), 4.03(5).

Totally, 2942 eggs, representing 652 clutches, were weighed during the laying period, i.e. they were not subjected to the marked continuous egg mass decline going on during the incubation (Figure 1, Nyholm unpubl.). Of these eggs, 1951 were weighed at their actual laying dates. In 391 complete clutches all eggs were weighed. The last eggs of these clutches were weighed at the day they were laid. These eggs might therefore have been incubated for some hours, but were considered to have lost weight insignificantly. In 269 of the complete clutches the eggs were numbered in laying order. Clutches which contained eggs with defective shells (cf. Nyholm \& Myhrberg 1977, Nyholm 1981, 2011) were not included in this study.

There are rather few studies on the mass of Pied Flycatcher eggs, but quite a number where egg sizes were presented in terms of volumes (V) as calculated from length (L) and breadth (B) measurements. Alternative formulas have been used for the volume calculations: $\mathrm{V}=0.5236 * \mathrm{~L}^{*} \mathrm{~B}^{2}$ (Bergtold 1929); $\mathrm{V}=0.4976 * \mathrm{~L}^{*} \mathrm{~B}^{2}-0.042$ (Ojanen et al. 1978 ); and $\mathrm{V}=0.51 * \mathrm{~L}^{*} \mathrm{~B}^{2}$ (Hoyt 1979).

To be able to compare the egg masses measured in the present study with those in other studies, a conversion factor between volume and mass (i.e. the specific density of the Pied Flycatcher eggs) was needed. Therefore 86 non-incubated Pied Flycatcher eggs representing 26 clutches were weighed as well as measured to length and breadth, and their volumes were assessed by use of each of the above mentioned formulas. When using the formula by Bergtold (1929), the mean estimated volume exceeded that obtained by the formulae according to Hoyt (1979) and Ojanen et al. (1978) by $2.6 \%$ and $7.6 \%$, respectively. The relatively low volume measure obtained with the latter formula is because it refers to the internal egg volume, while the others include the shell volume. The average length of the 86 eggs was $17.42 \mathrm{~mm}( \pm 0.804)$, breadth $13.19( \pm 0.342) \mathrm{mm}$, and the mean mass was 1.66 $\mathrm{g}( \pm 0.132)$, which gives the mean specific density $1.042( \pm 0.014) \mathrm{g} / \mathrm{cm}^{3}$ when applying the formula for volume calculation by Bergtold (1929), $1.070( \pm 0.014) \mathrm{g} / \mathrm{cm}^{3}$ by Hoyt (1979), and 1.128 ( \pm 0.016$) \mathrm{g} / \mathrm{cm} 3$ according to Ojanen et al. (1978). The formula by Bergtold (1929) probably gave the nearest correct measure of the egg volumes of the Pied Flycatcher population as the corresponding specific density value $\left(1.042 \mathrm{~g} / \mathrm{cm}^{3}\right)$ was closest to that of several other passerine bird species, 1.04$1.05 \mathrm{~g} / \mathrm{cm}^{3}$ (e.g. Enemar 1997). These values are considered as relevant alternative conversion factors from volume to mass of fresh Pied Flycatcher eggs. The choice of factor for conversion to egg mass from the egg volumes depends on the formula used for their volume calculation.

Female mass was measured using a $30 \mathrm{~g}$ Pesola balance during the incubation period, the breeding phase at which the mass of females are least variable (Lundberg \& Alatalo 1992).

The habitat quality, from the birds' view, at the separate nest box sites was judged from the nestbox attractiveness, i.e. the number of seasons the nest-box was chosen for breeding in relation to the number it was available (Potti 1993, Askenmo 1984). The habitat quality estimate was based on 323 complete clutches in wooden nest-boxes with standardized dimensions (Nyholm 2011).

Data regarding the local temperatures at Ammarnäs were obtained from the Swedish Meteorological and Hydrological Institute (SMHI). All statistical tests (Pearson's and Regression analyses) are two-tailed. Linear, quadratic, cubic, and linear stepwise regression models were applied, and corrected $\mathrm{r}^{2}$-values are presented, using IBM SPSS Statistics 21. Mean values are presented with their standard deviations.

\section{Results}

The mean mass of the all eggs across clutches and breeding seasons was $1.68 \pm 0.086 \mathrm{~g}$ (range 


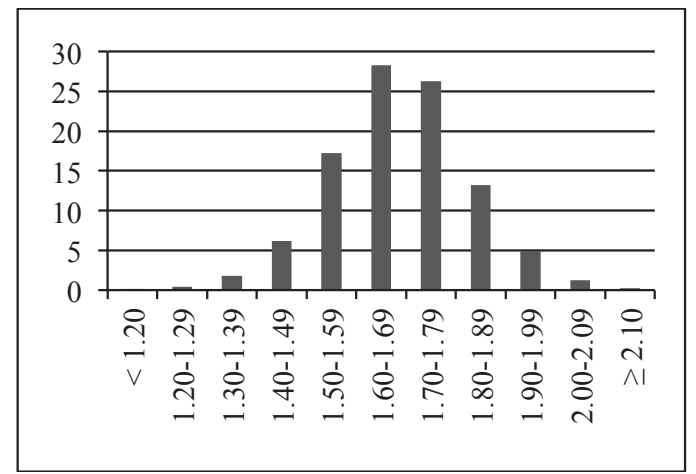

Figure 2. Percentage distribution (y axix) of 2942 Pied Flycatcher eggs across mass classes (x axis). Class breadth $=$ $0.1 \mathrm{~g}$.

Procentuell fördelning (y-axeln) av 2942 ägg av svartvit flugsnappare på viktklasser (x-axeln). Klassbredd $=0,1 \mathrm{~g}$.

1.11-2.23 g, $\mathrm{n}=2942$ eggs, Figure 2). Two eggs of 0.52 and $0.63 \mathrm{~g}$ (which lacked yolk, both were the first in their clutch) were excluded from all calculations. Across all eggs laid in a separate year the biggest eggs were 1.56 to 1.89 times heavier than the smallest.

The mean egg masses per clutch varied significantly between years (ANOVA: $\mathrm{F}=3.32, \mathrm{p}<0.001$, $\mathrm{n}=652$ clutches). The masses ranged from $1.63 \mathrm{~g}$ (1973) to $1.75 \mathrm{~g}$ (1975), i.e. the highest mean mass exceeded the lowest with about $7 \%$ (Table 1).

The mean mass of the eggs which were produced in different years by individual females were significantly correlated (linear regression $\mathrm{r}^{2}=0.46, \mathrm{p}$

Table 1 . The yearly variation in the average egg mass per clutch, 1965-1976.

Variationen hos äggmedelvikten per kull mellan olika år, 1965-1976.

\begin{tabular}{llllll}
\hline Year & \multicolumn{3}{c}{ Egg mass $\ddot{\text { gggvikt }}(\mathrm{g})$} & $\mathrm{N}$ \\
\cline { 2 - 5 } Ar & Mean & SD & Min & Max & Clutches \\
\hline 1965 & 1.70 & 0.126 & 1.44 & 1.94 & 38 \\
1966 & 1.72 & 0.126 & 1.45 & 1.98 & 48 \\
1967 & 1.67 & 0.152 & 1.44 & 1.99 & 28 \\
1968 & 1.71 & 0.111 & 1.51 & 1.99 & 35 \\
1969 & 1.68 & 0.125 & 1.38 & 1.98 & 105 \\
1970 & 1.71 & 0.123 & 1.49 & 2.02 & 96 \\
1971 & 1.65 & 0.110 & 1.41 & 1.93 & 55 \\
1972 & 1.72 & 0.135 & 1.40 & 1.95 & 26 \\
1973 & 1.63 & 0.125 & 1.38 & 1.83 & 30 \\
1974 & 1.67 & 0.123 & 1.35 & 2.01 & 104 \\
1975 & 1.75 & 0.151 & 1.50 & 2.08 & 54 \\
1976 & 1.67 & 0.143 & 1.42 & 2.03 & 33 \\
\hline
\end{tabular}

One way ANOVA: Mean egg mass: $\mathrm{F}=3.32$; $\mathrm{p}<0.001$

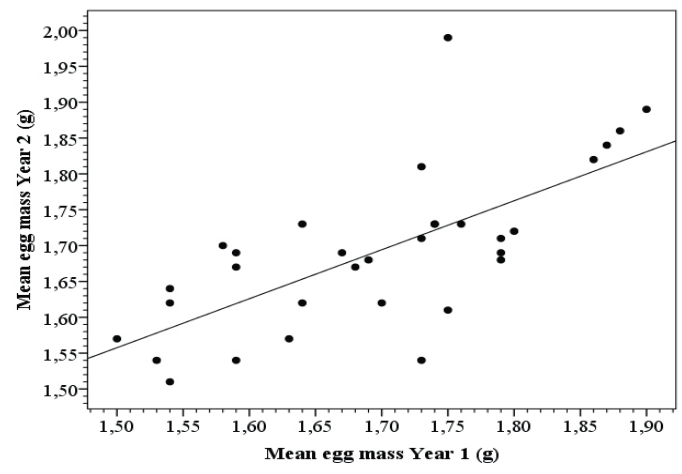

Figure 3 . The relation between the mean egg masses in clutches laid by the same females in different years.

Sambandet mellan äggmedelvikterna i kullar som värpts av samma honor olika år.

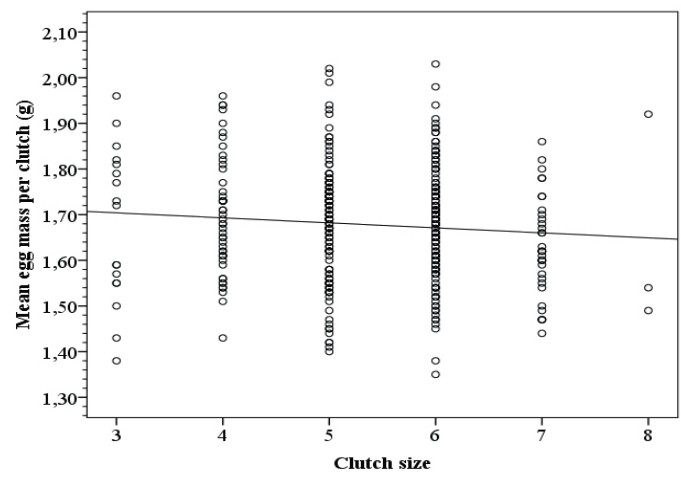

Figure 4. The relation between the mean egg mass per clutch and clutch size.

Relationen mellan kullars medeläggvikt och storlek.

$<0.001, \mathrm{n}=32$ between-year comparisons of 26 individuals, Figure 3), and did not differ between the years (Wilcoxon signed-rank test $\mathrm{p}=0.49, \mathrm{n}=$ 32 records).

Across all clutch sizes, the mean egg mass per clutch tended to be negatively related to clutch size (linear regression: $\mathrm{r}^{2}=0.005, \mathrm{~b}=-0.011, \mathrm{p}>0.08$, $n=391$ clutches, Figure 4$)$. The average egg mass-

Table 2. Mean egg mass per clutch at different clutch sizes. Äggens medelvikt per kull vid olika kullstorlekar

\begin{tabular}{llllll}
\hline Clutch size & \multicolumn{3}{c}{ Egg mass Äggvikt $(\mathrm{g})$} & \multirow{2}{*}{ N } \\
\cline { 2 - 5 } Kullstorlek & Mean & SD & Min & Max & Clutches \\
\hline 3 & 1.68 & 0.170 & 1.38 & 1.96 & 16 \\
4 & 1.70 & 0.128 & 1.42 & 1.96 & 47 \\
5 & 1.68 & 0.125 & 1.38 & 2.02 & 136 \\
6 & 1.68 & 0.115 & 1.35 & 2.03 & 158 \\
7 & 1.63 & 0.110 & 1.44 & 1.86 & 31 \\
8 & 1.65 & 0.237 & 1.49 & 1.92 & 3 \\
\hline
\end{tabular}


Table 3. The mean egg masses were not linearly related to the position of the eggs in the laying sequence at any clutch size.

Äggmedelvikten var oberoende av äggens plats $i$ värpordningen vid alla kullstorlekar. $N=$ Antal kullar.

\begin{tabular}{|c|c|c|c|c|c|c|c|}
\hline \multirow{2}{*}{$\begin{array}{l}\text { Clutch size } \\
\text { Kullstorlek }\end{array}$} & \multirow{2}{*}{$\begin{array}{l}\text { Egg no. } \\
\ddot{A g g ~} n r\end{array}$} & \multirow[b]{2}{*}{ Mean } & \multicolumn{3}{|c|}{ Egg mass vikt (g) } & \multirow{2}{*}{$\begin{array}{l}\mathrm{N} \\
\text { Clutches }\end{array}$} & \multirow{2}{*}{$\begin{array}{l}\text { Linear } \\
\text { regression }\end{array}$} \\
\hline & & & $S D$ & Min & $\operatorname{Max}$ & & \\
\hline \multirow[t]{3}{*}{3} & 1 & 1.68 & 0.209 & 1.24 & 1.95 & 12 & \multirow{3}{*}{$\mathrm{p}=0.71$} \\
\hline & 2 & 1.71 & 0.155 & 1.45 & 1.90 & 12 & \\
\hline & 3 & 1.70 & 0.099 & 1.51 & 1.87 & 12 & \\
\hline \multirow[t]{4}{*}{4} & 1 & 1.70 & 0.144 & 1.45 & 2.14 & 40 & \multirow{4}{*}{$\mathrm{p}=0.41$} \\
\hline & 2 & 1.70 & 0.132 & 1.46 & 2.05 & 40 & \\
\hline & 3 & 1.70 & 0.145 & 1.38 & 2.00 & 40 & \\
\hline & 4 & 1.67 & 0.155 & 1.36 & 1.98 & 40 & \\
\hline \multirow[t]{5}{*}{5} & 1 & 1.68 & 0.153 & 1.26 & 2.07 & 89 & \multirow{5}{*}{$\mathrm{p}=0.51$} \\
\hline & 2 & 1.69 & 0.132 & 1.31 & 2.03 & 89 & \\
\hline & 3 & 1.68 & 0.123 & 1.35 & 2.04 & 89 & \\
\hline & 4 & 1.69 & 0.120 & 1.34 & 2.04 & 89 & \\
\hline & 5 & 1.70 & 0.126 & 1.35 & 2.03 & 89 & \\
\hline \multirow[t]{6}{*}{6} & 1 & 1.67 & 0.142 & 1.11 & 2.02 & 97 & \multirow{6}{*}{$p=0.66$} \\
\hline & 2 & 1.70 & 0.128 & 1.43 & 2.23 & 97 & \\
\hline & 3 & 1.70 & 0.117 & 1.45 & 2.09 & 97 & \\
\hline & 4 & 1.69 & 0.118 & 1.32 & 2.05 & 97 & \\
\hline & 5 & 1.69 & 0.126 & 1.22 & 2.09 & 97 & \\
\hline & 6 & 1.69 & 0.137 & 1.24 & 2.15 & 97 & \\
\hline \multirow[t]{7}{*}{7} & 1 & 1.63 & 0.122 & 1.38 & 1.92 & 31 & \multirow{7}{*}{$\mathrm{p}=0.88$} \\
\hline & 2 & 1.63 & 0.113 & 1.45 & 1.86 & 31 & \\
\hline & 3 & 1.64 & 0.138 & 1.41 & 1.92 & 31 & \\
\hline & 4 & 1.64 & 0.104 & 1.45 & 1.84 & 31 & \\
\hline & 5 & 1.63 & 0.137 & 1.31 & 1.89 & 31 & \\
\hline & 6 & 1.64 & 0.130 & 1.39 & 1.89 & 31 & \\
\hline & 7 & 1.63 & 0.140 & 1.35 & 1.88 & 31 & \\
\hline
\end{tabular}

es of the 3 to 6 -egg clutches $(1.68-1.70 \mathrm{~g})$ were significantly higher than that of the pooled 7 and 8-egg clutches $(1.63 \mathrm{~g}$, t-test: $\mathrm{t}=2.30, \mathrm{p}<0.03$, Table 2). At none of the clutch sizes mean egg mass was significantly linearly related to the position in the laying sequence (Table 3 ). There was no significant relationship between female body mass and the mean mass of her eggs $\left(r^{2}=0.007, b=0.013\right.$, $p$ $=0.08, \mathrm{n}=278$ clutches, Figure 5).

The egg masses were significantly correlated to the daily mean temperatures of the day preceding the laying date (Pearson: $\mathrm{r}=0.12, \mathrm{p}<0.001$, $\mathrm{n}=1951$ eggs). Ambient temperatures and dates were significantly correlated (Pearson: $\mathrm{r}=0.28, \mathrm{p}$ $<0.001)$. The variation of egg mass over ambient temperature, and laying date, were best described by quadratic regression models $\left(\mathrm{r}^{2}=0.034, \mathrm{p}<\right.$ $0.001, \mathrm{n}=1953$ eggs, Figure 6; $\mathrm{r}^{2}=0.013, \mathrm{p}<$ $0.001, \mathrm{n}=1953$ eggs, Figure 7, respectively). The egg weight variation over the total temperature span was characterized by significantly increasing egg mass at temperatures lower than about $10^{\circ} \mathrm{C}$ $\left(b=0.014, r^{2}=0.028, p<0.001, n=1355\right.$ eggs $)$, whereas at higher temperatures egg masses showed a marginally significant decline $\left(b=-0.004, r^{2}=\right.$ $0.004, p=0.06 ; n=598$ eggs, Figure 6).

As to the relation between egg masses and laying date, the quadratic regression model indicated increasing egg masses at earlier dates than midJune, and decreasing masses at later dates (Figure 


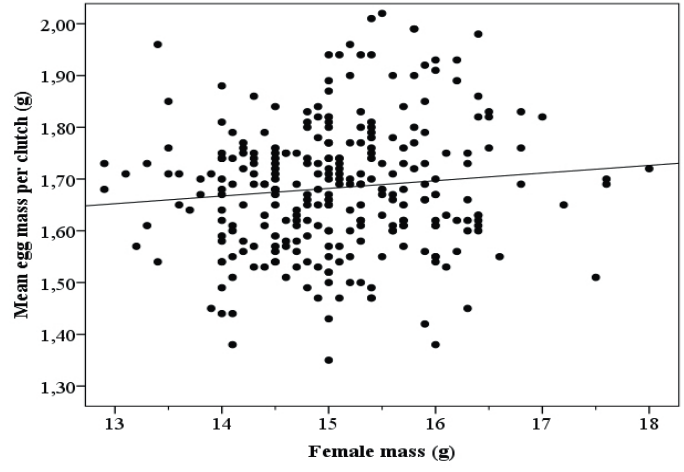

Figure 5. The relation between the female mass and mean mass of their eggs.

Förhållandet mellan honors vikter och medelvikt hos deras ägg.

7). Linear multiple regression analysis of the influences of ambient temperature and laying date on egg mass at the earlier dates showed that temperature and laying date together accounted for $2.3 \%(\mathrm{t}$ $=4.39, \mathrm{p}<0.001, \mathrm{n}=1502)$, and that temperature alone explained $1.6 \%(\mathrm{t}=3.39, \mathrm{p}<0.001)$ of the egg mass variation. The decreasing egg masses at the end of the laying period were mainly due to variation in laying date $(\mathrm{t}=-2.09, \mathrm{p}<0.04)$, while the ambient temperature, though increasing, had no significant effect on egg mass variation $(p>0.4)$.

Neither the mean egg mass nor the total egg mass per clutch was correlated with the habitat quality, as characterized by the nest box attractiveness $(\mathrm{r}=$ $0.05, \mathrm{p}>0.3$, and $\mathrm{r}=0.01, \mathrm{p}>0.9$, respectively; $\mathrm{n}$

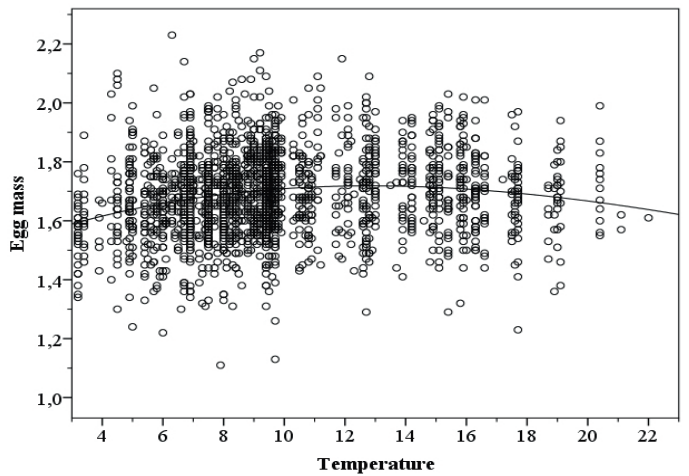

Figure 6. The relation between egg mass (g) and mean ambient temperatures $\left({ }^{\circ} \mathrm{C}\right)$ the day before the eggs were laid, 1965-1976. The line according to the quadratic regression model.

Relationen mellan äggvikt (g) och medeltemperaturen dygnet innan äggen värptes.Linjen enligt kvadratisk regressionsmodell.
$=323$ clutches). This was also valid for the 6-egg clutches separately, the most frequent clutch size ( $\mathrm{r}$ $=0.04, \mathrm{p}>0.6$, and $\mathrm{r}=0.05, \mathrm{p}>0.5$, respectively; $\mathrm{n}=145$ clutches).

\section{Discussion}

\section{Egg masses}

The mean mass (1.68 g) of Pied Flycatcher eggs at Ammarnäs was among the lowest reported. The regional range of mean egg masses, including those calculated from volume data with use of Bergtold's formula (see Study area and methods), was 1.67$1.78 \mathrm{~g}$ (Table 4). Pied Flycatcher eggs in subalpine birch forest at Kilpisjärvi, northernmost Finland, in 1975-1981, were reported to weigh $1.65 \mathrm{~g}$ (range $1.58-1.71 \mathrm{~g}$ ), i.e. less than at Ammarnäs, (Järvinen \& Väisänen 1983, 1984). These eggs were, however, incubated for $0-5$ days, during which time some mass loss most likely had taken place (cf. Figure 1). Based on the lengths and breadths measures of the eggs at Kilpisjärvi their mean mass was $1.74 \mathrm{~g}$ when un-incubated (Table 4). Also a number of the Pied Flycatcher eggs in Central Germany, which were weighed as well as measured to length and breadth by Sternberg \& Winkel (1970), might have been incubated for some time. That was indicated by that the mean mass of the eggs when weighed was $1.69 \mathrm{~g}$, but as judged from the presented length and breadth measures the eggs weighed $1.76 \mathrm{~g}$ when fresh (Table 4). The average masses of Pied Flycatcher eggs in the various studied populations were usually $1.74-1.78 \mathrm{~g}$. (Table 4). Lower mean egg masses, 1.67-1.68 g, were reported from

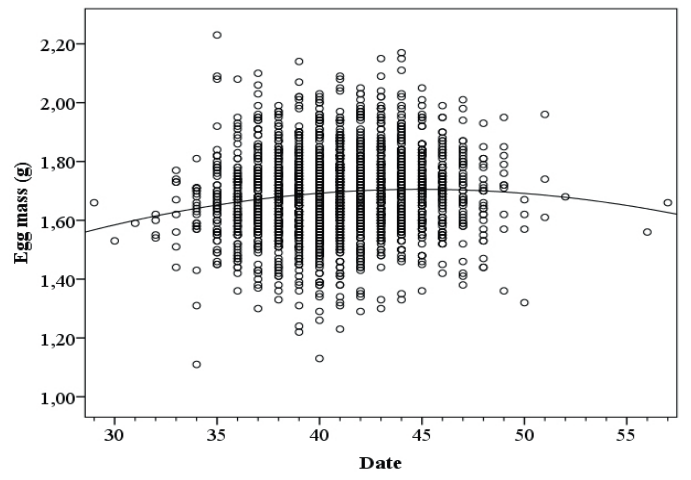

Figure 7. The relationship between egg mass (g) and dates one day before laying (1 = May 1st), 1965-1976.

Relationen mellan äggvikt (g) och datum dagen innan äggen värptes $(1=1 / 5)$ 
Table 4. Regional variation of mean individual egg mass in Pied Flycatcher. When the eggs in the original study were only measured (i.e. not weighed), egg mass was estimated using the formula of Bergtold (1929), assuming a specific mass of the eggs of $1.042 \mathrm{~g} / \mathrm{cm} 3$.

Äggmedelvikter hos svartvit flugsnappare $i$ andra delar av Europa. I de fall som äggen inte vägdes i orginalstudien (utan bara mättes) har vikten räknats fram (se text).

\begin{tabular}{lllrl}
\hline & $\begin{array}{l}\text { Mean } \\
\text { Medel } \\
\text { Region }\end{array}$ & $\begin{array}{l}\text { Range } \\
\text { Vidd } \\
(\mathrm{g})\end{array}$ & $\begin{array}{r}\text { Eggs } \\
\ddot{A g g}\end{array}$ & $\begin{array}{l}\text { Study } \\
\text { Undersökning }\end{array}$ \\
\hline C. Spain & $1.67^{\mathrm{m})}$ & & & \\
C. Europe & $1.74^{\mathrm{m})}$ & & 6350 & Potti 2008 \\
Mid-Germany & $1.76^{\mathrm{m})}$ & 286 & Makatsch 1976 \\
England & $1.76^{\mathrm{m})}$ & 1025 & Sternberg \& Winkel 1970 \\
Wales, UK & $1.68^{\mathrm{m})}$ & 100 & Witherby et al. 1938 \\
Wales, UK & $1.72 \mathrm{~m})$ & 175 & Slater \& Jennings 1987 \\
S. Finland & $1.74^{\mathrm{m})}$ & & 346 & Kern \& Cowie 1996 \\
Mid-Finland & $1.74^{\mathrm{m})}$ & & 427 & Järvinen \&Väisänen 1983 \\
Mid-Finland & $1.78^{\mathrm{m})}$ & & 4576 & Ojanen et al. 1978 \\
N. Finland & $1.74^{\mathrm{m})}$ & & 546 y) & Ojanen et al. 1981 \\
N. Finland & $1.74^{\mathrm{m})}$ & & 882 & Järvinen \& Väisänen 1984 \\
S. Norway & $1.75^{\mathrm{m})}$ & & 1679 & Järvinen 1991 \\
Mid-Norway & $1.77^{\mathrm{m})}$ & & 103 & Haftorn 1971 \\
N. Sweden & $1.66^{\mathrm{m}, \mathrm{w})}$ & & 190 & Slagsvold et al. 1984 \\
C. Spain & $1.68^{\mathrm{w})}$ & $1.29-2.03$ & 114 & This study \\
Mid-Germany & $1.69^{\mathrm{w}) \mathrm{z})}$ & & 319 & Sternberg \& Winkel 1970 \\
N. Sweden & $1.68^{\mathrm{w})}$ & $1.11-2.23$ & 2942 & This study \\
\hline
\end{tabular}

m) Mass calculated from volume (see text) Vikt beräknad från volym (se text)

w) Weighed eggs Äggen vägda

y) Only 6-7 egg clutches Enbart 6-7-äggkullar

z) See Discussion!

studies in central Spain (Potti 1993, 2008), central Wales (Slater \& Jennings 1987), and northern Sweden (the present study), all three in mountain areas. The breeding habitats of the present study were characterized by harsh and variable weather conditions, which regularly affected the breeding course of the species (Nyholm 2011, Thingstad et al. 2006).

It seems noticeable that the mean mass of Pied Flycatcher eggs in subalpine habitats at Kilpisjärvi (1975-1987), $1.74 \mathrm{~g}$ (as calculated from Järvinen \& Väisänen 1984 and diagram in Järvinen 1989; Table 4), was so much higher than at Ammarnäs. This was despite lower mean temperatures during the laying periods, $6.6^{\circ} \mathrm{C}$ at Kilpisjärvi (Järvinen 1991 ) and $9.3^{\circ} \mathrm{C}$ at Ammarnäs. Besides bigger eggs, the average clutch sizes were bigger at Kilpisjärvi despite two days later mean laying start (mean $5.7 \pm 0.98$ eggs/clutch, $\mathrm{n}=353$ clutches, Järvinen 1989) than at Ammarnäs 1965-1976, (mean $5.5 \pm$
1.03 eggs/clutch, $\mathrm{n}=1628$ clutches; $\mathrm{t}=3.50, \mathrm{p}<$ $0.001)$. The greater egg mass in Finland could indicate that the breeding conditions (food availability?), though harsher climate during the egg laying periods, generally were more favorable for the Pied Flycatchers at Kilpisjärvi than at Ammarnäs.

\section{Yearly egg mass variation}

The variation of mean egg mass between years was significant (Table 2), and similar to those in two other long-term studies, both performed in peripheral habitats. At La Hiruela in central Spain 19882006 (Potti 2008), at Kilpisjärvi in northern Finland 1975-1987 (Järvinen 1989), and at Ammarnäs 1965-1976 the coefficients of variation (CV) of the yearly mean egg masses were $2.0-2.1 \%$. The differences between the lowest and highest yearly mean egg masses were 6-7\% in these studies. The between year variation of egg mass was probably 
ultimately related to variation in environmental factors during the laying periods. As to climatic conditions, the mean ambient temperatures during the egg-laying period at Ammarnäs were below $10^{\circ} \mathrm{C}\left(7\right.$ to $\left.9^{\circ} \mathrm{C}\right)$ in eight of the twelve years, and exceeded $10^{\circ} \mathrm{C}$ only in $1965,1966,1970$, and 1972.

The variation of egg mass between breeding seasons in individual females was non-significant, which indicated a high degree of repeatability of egg size (Figure 3). This was in concordance with findings in a Pied Flycatcher population in Central Spain (Potti 1993). In contrast to the Spanish study, no trend towards decreased egg size with advancing female age could be seen in the present study (Year 1 vs Year 2, paired t-test: $\mathrm{t}=0.29, \mathrm{p}>0.77$ ).

\section{Egg mass/clutch size relations}

Data on the relation between egg size and clutch size in the Pied Flycatcher are inconclusive. Järvinen \& Väisänen (1983) reported a negative correlation between egg size and clutch size in southern Finland but a positive relation in the sub-alpine habitats in northern Finland (Kilpisjärvi). However, no relation was found in an extended study period at Kilpisjärvi (Järvinen 1991). Likewise, Ojanen et al. (1978) found no relationship between egg size and clutch size in Pied Flycatchers breeding in mid-Finland. Potti (1993) reported that the relation between clutch size and egg size varied between years in Central Spain.

The negative, but non-significant, correlation between egg mass and clutch size in the present study (Figure 4) was conditioned by the significantly smaller eggs in the 7 and 8-egg clutches than in the 3 to 6-egg clutches. The smaller sizes of the eggs in the former clutches were not related to the factors shown to influence egg size, i.e. lower ambient temperature or lower female mass. The laying of the 7 and 8-egg clutches were started on average three to four days earlier than the smaller clutches, but the mean ambient temperature during the egg development $\left(9.9^{\circ} \mathrm{C} \pm 0.71\right)$ did not differ significantly from the corresponding temperatures for the 3 to 6 -egg clutches $(10.3 \pm 0.18,10.2 \pm 0.19,10.1 \pm$ 0.21 , and $9.8^{\circ} \mathrm{C} \pm 0.25$, respectively). The females of the 7 and 8 -egg clutches were on average heavier (15.3 $\mathrm{g} \pm 0.77, \mathrm{n}=25)$, though not significantly, than those which laid the 3 to 6 -egg clutches (15.0 $\mathrm{g} \pm 0.88, \mathrm{n}=253, \mathrm{~F}=2.85, \mathrm{p}<0.10)$. The total egg masses produced by the females of 7,6 , and 5 egg-clutches corresponded on average to $75 \%$, $67 \%$, and $45 \%$ of their body masses, respectively.
The smaller difference between the female investments in eggs in 7 and 6 egg-clutches than between 6 and 5 egg-clutches, was due the about 3\% lower mean mass per egg in the 7 egg-clutches than in the 5 and 6-egg-clutches. The significance, in ecophysiological terms, of the lower mean egg mass in the 7-egg-clutches of Pied Flycatchers at Ammarnäs seems unclear (cf. Enemar 1997).

\section{Intra-clutch egg mass variation}

The intra-clutch variation in egg size is far from uniform between species, and also within the same species (Enemar 1997). In the Pied Flycatcher Ojanen et al. (1981), Ojanen (1983), Slagsvold et al. (1984), Ylimaunu \& Järvinen (1987), Slagsvold \& Lifjeld (1989), and Potti (1993) observed a more or less continuously increasing egg size in the laying sequence. In contrast, the egg sizes in the laying sequence showed no trend in the present study. This was valid independently of clutch size (Table 3). In the great majority of the clutches, and wherever in the laying sequence, one to all eggs were laid at ambient temperatures low enough to affect their sizes more or less. Possibly, a relation between egg mass and position in the laying order could be concealed. Therefore, the intra-clutch egg size variations in 5 to 7 -egg clutches with all eggs laid at temperatures high enough to not significantly affect egg mass, i.e. at daily mean temperatures being higher than $9.5^{\circ} \mathrm{C}$, were analysed separately, but the mean mass of the eggs in the laying sequence varied non-significantly also in these clutches (Figure 8).

Increasing egg size with the position in the laying sequence is suggested to be a strategy to govern the survival of the latest hatched nestlings at asynchronous hatching (Enemar 1997). The majority of the clutches of the Pied Flycatcher population (and several other passerine populations) at Ammarnäs showed developmental asynchrony, the degree of which ranged from 0.5 to about 2 days (Enemar \& Arheimer 1989). The asynchrony was conditioned by increased incubation intensity from one to two days preceding the clutch completion. The results of the present study did thus not support the notion that hatching asynchrony is correlated to increasing masses of the last eggs in the laying sequence. But the results were not contradictory to that the Pied Flycatcher intra-clutch egg size variation in cold habitats may be ultimately driven by the ambient temperature during the egg formation (Järvinen \& Ylimaunu 1986). 


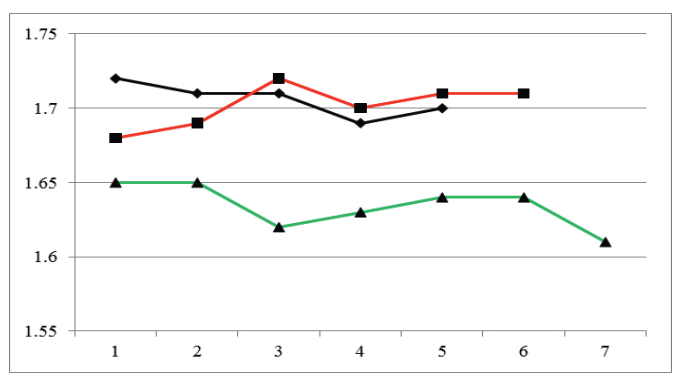

Figure 8 . The mean mass (g; y axis) of the eggs in the laying sequence ( $\mathrm{x}$ axis) in 5, 6, and 7 egg clutches, all formed at ambient temperatures being $>9.5^{\circ} \mathrm{C}$ the day before the egg was laid. Statistics: Linear regression: 5, 6, and 7 egg clutches: $\mathrm{p}>0.68 ; \mathrm{N}=31$ clutches, $\mathrm{p}=0,20 ; \mathrm{N}=33$, and $\mathrm{p}=0.68$; $\mathrm{N}=7$, respectively.

Vikt (gram, y-axeln) hos ägg $i$ värpsekvensen ( $x$-axeln) för kullar med 5,6 och 7 ägg, som alla har formats vid högre utetemperaturer än $9,5^{\circ} \mathrm{C}$.

\section{Relation between female mass and egg mass}

The masses of the Pied Flycatcher females and their eggs showed a weak correlation in the present population (Figure 5), in comparison with populations in Finnish Lapland (Järvinen \& Väisänen 1984, Järvinen 1991), southern Sweden (Askenmo 1977), and Central Spain (Potti 1993). Female mass in studied passerine species generally account for less than $15 \%\left(\mathrm{r}^{2}\right)$ of the variation in egg size, but in the Pied Flycatcher usually less than 10\% (Christians 2002). In the present study the female mass accounted for only about $1 \%$ of the egg mass variation, which was 4 to 10 times less than noticed in other Pied Flycatcher studies (Ojanen et al. 1979; Järvinen \& Väisänen 1983, 1984, Järvinen 1991, Potti 1993).

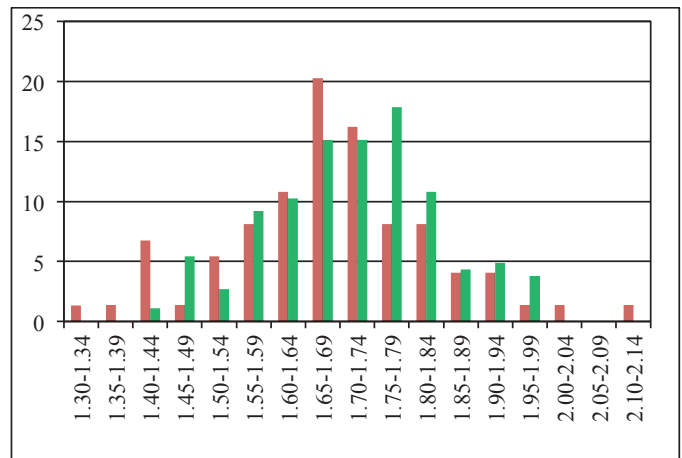

Figure 9. Percentage distribution (y axis) of rates of hatched (green) and unhatched (red) eggs over egg mass classes ( $\mathrm{g}$; $\mathrm{x}$ axis) in clutches partially struck by hatching failure. $\mathrm{N}=185$ hatched eggs and 74 unhatched eggs in the same 54 clutches. Procentuella fördelningar (y-axeln) av andelar kläckta (grönt) respektive okläckta (rött) ägg, uppdelat på viktklasser (g; x-axeln) i 54 kullar med minst ett okläckt ägg.
The relatively low degree of relation between female mass and egg mass at Ammarnäs could at least partly be related to different climatic situations when the eggs and, later, the females were weighed. This is indicated by that the relation between the masses of females and their eggs was significant when the females were weighed and all their eggs were formed at ambient temperatures above $10^{\circ} \mathrm{C}\left(\mathrm{r}^{2}=0.03, \mathrm{p}<\right.$ $0.04, n=43$ clutches). At lower temperatures, when female mass as well as egg mass were suppressed, the relation was non-significant $\left(<10^{\circ} \mathrm{C}, \mathrm{r}^{2}=0.00\right.$, $\mathrm{p}$ $>0.35, \mathrm{n}=144$ clutches).

\section{Egg mass and breeding success}

A question that arises is whether the frequently reduced egg sizes at Ammarnäs affected the breeding success of the Pied Flycatcher population. As observed in 54 clutches which all were struck by partial hatching failure, the masses of the unhatched eggs ( 74 out of totally 259 eggs) were distributed over the whole mass scale, but were especially frequent among the relatively few eggs which weighed less than $1.45 \mathrm{~g}$ (Figure 9). Also the few eggs which weighed more than $2 \mathrm{~g}$ remained unhatched. Seen to all the weighed eggs, only $4.5 \%$ $(131 / 2942)$ weighed less than $1.45 \mathrm{~g}$, and $1.5 \%$ weighed more than $2.00 \mathrm{~g}$. The smallest egg observed to hatch weighed only $1.28 \mathrm{~g}$. This occurred in one of totally eight 5 to 7-egg clutches in which all eggs hatched, and in which 1 to 6 eggs (totally 20 eggs) weighed less than $1.45 \mathrm{~g}$. It is noteworthy that all the 47 eggs of these clutches were relatively small, on average weighing $1.47 \mathrm{~g}( \pm 0.09)$, and that the majority of them were laid at ambient temperatures exceeding $10 \mathrm{C}^{\circ}$ by females weighing $15.0 \mathrm{~g}$ on average. As a suggestion, therefore, the small sizes of these eggs were due to some constitutional female factor rather than environmental factors.

Hatching success, as measured in successful clutches, was not related to the mean egg mass ( $\mathrm{r}$ $=0.14, \mathrm{p}>0.77, \mathrm{n}=415$ clutches). The same was true for the fledging success in these clutches $(r=$ $-0.24, p>0.63)$. This indicates that mean egg sizes were not decisive of the breeding results, and that females were capable to fulfill their breeding successfully even though they at times probably were at reduced condition due reduced food availability at frequent periods with low ambient temperature. From Kilpisjärvi in North Finland, Järvinen \& Väisänen (1983) report that hatching rate and egg size in the Pied Flycatcher were related. As calculated from their Figure 6, the mean mass of the eggs 
Table 5. The relationship between variations of masses of separate eggs and clutch size, female weight, ambient temperature, and laying date (stepwise multiple regression).

Relation mellan äggvikt och kullstorlek, honors vikt, omgivningstemperatur och värpdatum (stegvis multipel regression).

\begin{tabular}{llll}
\hline & $\mathrm{r}^{2}$ & \multicolumn{2}{l}{ Change Ändring } \\
& & $\mathrm{F}$ & $\mathrm{p}$ \\
\hline $\begin{array}{l}\text { Clutch size Kullstorlek } \\
\text { Clutch size, temperature }\end{array}$ & 0.020 & 19.34 & $<0.001$ \\
$\begin{array}{l}\text { Kullstorlek, temperatur } \\
\text { Clutch size, temperature, female weight }\end{array}$ & 0.038 & 18.41 & $<0.001$ \\
Kullstorlek, temperatur, honans vikt & & & \\
\hline
\end{tabular}

Addition of Laying date did not contribute significantly to explain egg weight variation. $\mathrm{N}=910$ (all variables). Läggdatum bidrog inte signifikant till att förklara viktvariationen.

in clutches which totally failed to hatch at Kilpisjärvi was $1.68 \mathrm{~g}$. The hatching failure was ascribed to these eggs being laid by females which could not incubate effectively enough due to reduced condition during cold spells, and that the smaller eggs are more sensitive to cold weather.

Egg size showed no tendency to be related to varied nest box attractiveness (habitat quality) in contrast to findings in a Pied Flycatcher population in Central Spain (Potti 1993).

In conclusion, the egg production of the Pied Flycatchers breeding in the subalpine habitats at Ammarnäs was affected at the predominant ambient temperature levels. As much as about seventy percent of the eggs were formed at ambient mean temperatures being 3-9.5 $\mathrm{C}^{\circ}$, at which egg sizes showed a significantly increasing trend with temperature. Also the female masses were lower at that low temperature level, probably reflecting decreased female condition. Frequent periods of low temperature at Ammarnäs, occurring at any part of the laying period, contributed to explain why the mean mass of the produced eggs was lower than generally observed elsewhere, and also that the egg mass varied significantly between years. The variation in egg mass in the present study deviated from that observed in other studies on the Pied Flycatcher in that the mass were unrelated to the order in the laying sequence. A significant negative relation between laying date on egg mass, which was shown at the end of the laying period, was tentatively related to mismatched food availability for optimal egg formation. It was also observed that egg mass was related to clutch size, in the way that eggs in the 7 to 8-egg clutches weighed less than those in smaller clutches. The females laying these clutches deviated by on average being heavier (bigger?) than those laying heavier eggs in smaller clutches. Despite the fact that the eggs in the 7-egg clutches were smaller than in the four to six egg clutches they gave rise to the highest hatchling $(82 \%$ and $68 \%$, respectively) and fledgling (74\% and 57\%, respectively) rates (in 158 and 1271 clutches respectively. The variables which were found to significantly, or close to significantly, influence egg mass, i.e. clutch size, ambient temperature, females mass, and laying date together accounted for less than $6 \%$ of the egg mass variation (Table 5). This means that the by far largest part of the egg mass variation remains unexplained.

The study shows that the egg masses of Pied Flycatchers which bred in the subalpine birch forest at Ammarnäs 40-50 years ago frequently were restricted at harsh climatic conditions. So egg mass might be an applicable variable when to follow possible effects of a predicted climate change in subalpine habitats (cf. Järvinen 1994).

\section{Acknowledgements}

The study was supported by grants from the Swedish Natural Research Council to Prof. A. Enemar. The field work was performed in cooperation with the late Harry Myhrberg. I am also thankful to Åke Lindström and two anonymous reviewers for constructive comments on the manuscript.

\section{References}

Askenmo. C. 1977. Some aspects of the reproduction strategy of the Pied Flycatcher Ficedula hypoleuca (Pallas). Ph.D. Thesis, Dept of Zoology, Univ. of Gothenburg, Sweden.

Askenmo, C.E.H.1984. Polygyny and nest site selection in Pied Flycatcher. Anim.Behav. 32: 972-980. 
Bergtold, W. H. 1929. Egg weights from egg measurements. Auk 46: 466-473.

Christians, J.K. 2002. Avian egg size: variation within species and inflexibility within individuals. Biol. Rev. 77: $1-26$.

Hoyt, D. F. 1979. Practical method of estimating volume and fresh weight of bird eggs. Auk 96: 73-77.

Enemar, A. 1997. The egg size variation of the Treecreeper Certhia familiaris in south-western Sweden. Ornis Svecica 7: 107-120.

Enemar, A. \& Arheimer, O. 1989. Developmental asynchrony and onset of incubation among passerine birds in a mountain birch forest of Swedish Lapland. Ornis Fennica 66: 32-40.

Kern, M.D. \& Cowie, R.J. 1996. The size and shape of eggs from a Welsh population of Pied Flycatcher - Testing Hoyt's use of egg dimensions to ascertain egg volume. $J$. Field Ornithol. 67: 72-81.

Järvinen, A. 1989. Patterns and causes of long-term variation in reproductive traits of the Pied Flycatcher Ficedula hypoleuca in Finnish Lapland. Ornis Fennica 66: 24-31.

Järvinen, A. 1991. Proximate factors affecting egg volume in subarctic hole-nesting passerines. Ornis Fennica 68: 99-104.

Järvinen, A. 1994. Global warming and egg size of birds. Ecography 17:108-110.

Järvinen, A. \& Väisänen, R.A. 1983. Egg size and related reproductive traits in a southern passerine Ficedula hypoleuca breeding in an extreme northern environment. Ornis Scand.14: 253-262.

Järvinen, A. \& Väisänen, R.A. 1984. Reproduction of pied flycatcher (Ficedula hypoleuca) in good and bad breeding seasons in northern marginal area. Auk 101: 439-450.

Järvinen, A. \& Ylimaunu, J. 1986. Intraclutch egg-size variation in birds: Physiological response of individuals to fluctuations in environmental conditions. Auk 103: 235-237.

Lundberg, A. \& Alatalo, R.V. 1992. The Pied Flycatcher. T. \& A.D.Poyser, London.

Nyholm, N. E. I. 2011. Dynamics and reproduction of a nest-box breeding population of Pied Flycatcher Ficedula hypoleuca in a subalpine birch forest in Swedish Lapland during a period of 46 years. Ornis Svecica 21: 133-156.

Nyholm, N.E.I. 1981. Evidence of involvement of aluminum in causation of defective formation of eggshells and of impaired breeding in wild passerine birds. Environm. Res. 26: 363-371.

Nyholm, E. \& Ginstrup, O. 1968. A balance for weighing eggs of smaller birds in the field. Oikos 19: 149-151.

Nyholm, N.E.I. \& Myhrberg, H.E. 1977. Severe eggshell defects and impaired reproductive capacity in small passerines in Swedish Lapland. Oikos 29: 336-341.

Ojanen, M. 1983. Effects of the laying sequence and ambient temperature on the composition of eggs of the Great Tit Parus major and the Pied Flycatcher Ficedula hypoleuca. Ann. Zool. Fennici 20: 65-71.

Ojanen, M., Orell, M. \& Väisänen, R.A. 1978. Egg and clutch sizes in four passerine species in northern Finland. Ornis Fennica 55: 60-68.

Ojanen, M., Orell, M. \& Väisänen, R.A. 1979. Role of heredity in egg size variation in the Great Tit Parus major and the Pied Flycatcher Ficedula hypoleuca. Ornis. Scand. 10:22-28

Ojanen, M., Orell, M. \& Väisänen, R.A. 1981. Egg size vari- ation within passerine clutches: effects of ambient temperature and laying sequence. Ornis Fennica 58: 93-108.

Potti, J. 1993. Environmental, ontogenetic, and genetic variation in egg size of Pied Flycatchers. Can. J. Zool. 71: 1534-1542.

Potti, J. 2008. Temperature during egg formation and the effect of climate warming on egg size in a small song bird. Acta Oecologica 33: 387-393.

Slagsvold, T. \& Lifjeld, J.T. 1989. Constraints on hatching asynchrony and egg size in Pied Flycatchers. J. Anim. Ecol. 58: 837-849.

Slagsvold, T., Sandvik, J., Rofstad, G., Lorentsen, Ö. \& Husby, M. 1984. On the adaptive value of intraclutch egg-size variation in birds. Auk 101: 685-697.

Slater, F.M. \& Jennings, P.P. 1987. Aberrant eggs of Pied Flycatchers Ficedula hypoleuca in Mid-Wales. Bird Study 34: 185-186.

Sternberg, H. \& Winkel, W. 1970. Über die Ei-Grösse des Trauerschnäppers (Ficedula hypoleuca) und ihre Beziehung zu Zeit, Alter und Biotop. DieVogelwarte 25: 260267.

Thingstad, P.G., Nyholm, N.E.I. \&, Fjeldheim, B. 2006. Pied flycatcher Ficedula hypoleuca population dynamics in peripheral habitats in Scnadinavia. Ardea 94: 211-223.

Ylimaunu, J. \& Järvinen, A. 1987. Do Pied Flycatchers Ficedula hypoleuca have a brood-survival or brood reduction strategy? Ornis Fennica 64: 10-15.

\section{Sammanfattning}

1965-1976 vägdes ägg av svartvit flugsnappare häckande i fjällbjörkskog, den mest perifera biotopen inom artens utbredningsområde i norra Sverige, och dit arten relativt nyligen invandrat. Här kunde det förväntas att häckningsförloppet, bland annat äggproduktionen, påverkas av kärva väderförhållanden. Därför registrerades, förutom kullstorlek, också äggens vikt som ett mera detaljerat mått på äggproduktionskapaciteten. Artikeln behandlar variationen hos äggens vikt i relation till utetemperatur, häckningssäsong, kullstorlek, position i värpsekvensen, honans vikt, biotopens kvalitet och betydelse för häckningsresultat under de tolv säsongerna.

\section{Metoder}

Studierna gjordes i holkhäckande populationer 500-650 $\mathrm{m}$ ö $\mathrm{h}$ på sydsluttningarna av fjällen Gaisatj och Valle ca $8 \mathrm{~km}$ väster om Ammarnäs, Lappland. Äggen vägdes i fält med noggrannheten $\pm 0.01 \mathrm{~g}$ med en våg som speciellt konstruerats för att väga småfågelägg. Totalt vägdes 2942 ägg från 652 kullar under värpperioden, d v s innan äggvikterna påverkats av den viktminskning som sker under ruvning (se Figur 1). Det finns bara ett fătal uppgifter som jämförelse om äggvikter för svartvit flugsnappare från andra delar av utbredningsom- 
rådet. Däremot har äggens volym beräknats med olika metoder och presenterats som storleksmått från flera populationer. Utifrån 86 ägg som både mättes och vägdes bedömdes att metoden för volymberäkning enligt Bergtold (1929) och specifika vikten $1,042 \mathrm{~g} / \mathrm{cm}^{3}$ vara lämpligast för att omvandla mått till vikt för svartvit flugsnapparäggen.

Honors vikt mättes med $30 \mathrm{~g}$ Pesola-våg under ruvningsperioden, den häckningsfas då deras vikt varierar minst.

Häckningsbiotopens kvalitet bedömdes från antalet säsonger som respektive holk valdes för häckning i relation till hur många säsonger den var tillgänglig.

Uppgifter om lokala temperaturer erhölls från SMHI.

\section{Resultat}

Sett över alla äggen och säsongerna varierade vikterna mellan 1,11 och 2,23 g, med medelvikt 1,68g, och fördelades mellan viktklasser enligt Figur 2. Under de olika säsongerna var de tyngsta 1,56 till 1.89 gånger tyngre än de lättaste äggen.

Äggens medelvikter varierade signifikant mellan åren (Tabell 1).

Medelvikterna hos ägg som värpts av samma hona under olika år var signifikant korrelerade $(\mathrm{p}>0,001, \mathrm{n}=32$ ) (Figur 3) och skiljde sig inte mellan åren $(\mathrm{p}=0,49)$.

Sett över alla kullstorlekar var äggmedelvikten per kull svagt relaterad till kullstorleken ( $\mathrm{p}>0,08$, Figur 4, Tabell 2). Medelvikterna hos 3-6-äggkullarna $(1,68-1,70 \mathrm{~g})$ var emellertid högre än hos 7-8-äggkullarna (1,63 g, $\mathrm{p}<0,03)$.

För varje kullstorlek var medelvikterna för ägggen oberoende av deras position i värpsekvensen (Tabell 3). Äggens medelvikt var inte signifikant relaterad till honans vikt ( $>00,08$, Figur 5).

Utetemperaturen dygnet före äggen värptes (d.v.s. då äggen utvecklades) hade signifikant påverkan på äggens vikt. Denna beskrevs bäst med den kvadratiska regressionsmodellen (Figur 6). Vid medeltemperaturer under ca $10^{\circ} \mathrm{C}$ ökade äggvikterna med temperaturen, medan de tenderade att minska vid högre temperaturer. Multipel regressionsanalys med temperatur och värpdatum (vilka är starkt relaterade) som oberoende och äggvikt som beroende variabler visade att temperatur förklarade största delen av äggviktens variation vid lägre temperaturer än $10^{\circ} \mathrm{C}$, medan viktvariationen vid högre temperaturer påverkades av värpdatum, men inte av temperatur, $(<0,04$ respektive $\mathrm{p}>0,4$ ).
Varken äggens medelvikt eller äggens sammanlagda vikt per kull skiljde sig mellan olika häckningsbiotoper.

\section{Diskussion}

Medelvikten $(1,68 \mathrm{~g})$ hos flugsnapparäggen vid Ammarnäs var bland de lägsta som rapporterats. Från olika delar av artens utbredningsområde har presenterade medelvikter varierat från $1,67 \mathrm{~g}$ till $1,78 \mathrm{~g}$ (inklusive de som beräknats från volymuppgifter enligt Bertold's beräkningsmetod (Tabell 4). De lägsta medelvikterna har uppmätts i bergsområden, i centrala Spanien, centrala Wales och Ammarnäs. Det ses som anmärkningsvärt att medelvikten hos ägg i fjällbörkskog i Kilpisjärvi (norra Finland) var betydligt högre än vid Ammarnäs trots att medeltemperaturen under värpperioderna var lägst i Kilpisjärvi $\left(6,6\right.$ respektive $\left.9,3^{\circ} \mathrm{C}\right)$. Att häckningsförhållandena i Kilpisjärvi var allmänt gynnsammare än vid Ammarnäs trots de lägre temperaturerna stöds av att även medelkullstorleken var högre, trots senare häckningsstart (5,7 respektive 5.5 ägg/kull).

Variationen hos äggmedelvikten mellan åren i Ammarnäs (Tabell 2) var den samma som i två andra långtidsstudier (i centrala Spanien och i Kilpisjärvi; 19 respektive 13 säsonger). I Ammarnäs var variationen sannolikt beroende av varierade omgivningsfaktorer, såsom klimatförhållandena. Under åtta av de tolv säsongerna var medeltemperaturerna under värpperioderna $7-9^{\circ} \mathrm{C}$, och översteg $10^{\circ} \mathrm{C}$ endast $1965,1966,1970$ och 1972.

Äggvikterna hos enskilda honor skiljde sig inte mellan år, vilket tydde på hög grad av konstans (Figur 3). Detta var i överensstämmelse med observationer i spanska populationer.

Olika undersökningar visar olika resultat beträffande sambandet mellan äggvikt och kullstorlek. Denna studie visar att medelvikterna hos äggen $\mathrm{i}$ kullar med 3-6 ägg var lika men att de var betydligt högre än i kullarna med 7-8 ägg. Skillnaden kunde inte förklaras med faktorer som visats kunna påverka äggens vikt. Äggen i kullarna med 7-8 ägg var mindre trots att de var värpta vid samma utetemperaturer som äggen i de mindre kullarna, och att honorna till de större kullarna snarare var tyngre än de till kullarna med 3-6 ägg (medelvikter15,3g respektive $15,0 \mathrm{~g}, \mathrm{p}<0,10$ ).

Flera undersökningar har påvisat en ökande äggstorlek med positionen i värpsekvensen. I motsats till dessa visade denna studie ingen sådan trend (Tabell 3). För att se om detta kunde bero på att eventuell trend doldes av att vikten hos åtskilliga 
ägg påverkats av låga temperaturer studerades kullar där alla äggen värptes vid temperaturer som visats inte påverka äggvikterna. Inte heller i dessa kullar varierade vikterna hos äggen i värpsekvensen (Figur 8).

Ökande äggstorlek i värpsekvensen har föreslagits vara en strategi till att öka överlevnad för de senast kläckta ungarna vid asynkron kläckning. I de flesta kullarna i populationen vid Ammarnäs är kläckningen asynkron (Enemar \& Arheimer 1989). Denna studie gav alltså inget stöd för att asynkron kläckning är korrelerad till ökad äggstorlek i värpsekvensen.

Honans vikt förklarade bara $1 \%$ av variationen hos äggens vikt i denna undersökning (Figur 5), vilket var 4 till 10 gånger lägre förklaringsgrad än den som påvisats för svartvit flugsnappare från flera håll i Finland och i Spanien. Det låga sambandet mellan honvikt och äggvikt denna undersökning kunde åtminstone delvis bero på att temperaturförhållandena var olika då äggen respektive honorna vägdes. Detta antyds av att sambandet var starkare $(3 \%, \mathrm{p}<0,04)$ då analysen begränsades till honor som vägdes och vars ägg utvecklades vid temperaturer som alla översteg $10^{\circ} \mathrm{C}$.

Frågan är om de ofta förekommande reducerade äggstorlekarna påverkade svartvit flugsnapparens häckningsresultat. I kullar i vilka en andel ägg inte kläcktes fördelades de okläckta äggen vikter hela viktskalan, men dominerade speciellt bland det fåtal ägg som vägde mindre än 1,45 g (Figur 9). Också de få ägg som vägde mer än 2 gram förblev okläckta. Bland alla vägda ägg vägde bara $4,5 \%$ mindre än $1,45 \mathrm{~g}$ and 1,5\% vägde mer än 2,00 g. Det minsta ägg som kläcktes vägde endast $1,28 \mathrm{~g}$.

Andelarna kläckta ägg och utflugna ungar i kullar med lyckad häckning var inte relaterad till medelvikten hos äggen $(p>0,77$ respektive $p>0,63)$. Detta antyder att äggvikterna inte var avgörande för häckningsresultaten. Undersökning i Kilpisjärvi påvisar, till skillnad från denna undersökning, ett samband mellan äggvikt och kläckningsfrekvens.

Relation mellan häckningsbiotopens kvalitet, vilket inte kunde påvisas i denna undersökning förekom hos en svartvit flugsnapparpopulation i Spanien.

De variabler som påvisades påverka äggvikterna signifikant, eller nära signifikant, d.v.s. kullstorlek, utetemperatur, honvikt och värpdatum förklarade mindre än $6 \%$ av äggviktens variation, vilken sålunda är oförklarad till helt övervägande del (Tabell 5).

Undersökningen visar att vikterna hos svartvit flugsnapparens ägg i den subalpina björkskogen vid Ammarnäs var påverkade av klimatsituationen för 40-50 år sedan. Detta talar för att äggvikt skulle kunna vara en användbar variabel för att påvisas möjliga effekter av klimatförändringar i den subalpina miljön. 